UDC 338.2:330.3

DOI: https://doi.org/10.37320/2415-3583/12.14

\author{
Savchenko Olga \\ Candidate of Sciences (Economics), Associate Professor, \\ National Technical University "Kharkiv Polytechnic Institute» \\ ORCID: https://orcid.org/0000-0002-4407-6387 \\ Turan Ugur \\ Postgraduate Student, \\ National Technical University "Kharkiv Polytechnic Institute" \\ ORCID: https://orcid.org/0000-0003-2168-5232
}

\title{
RESEARCH ON UKRAINE'S SUSTAINABLE DEVELOPMENT GOALS AND COMPARISON WITH THE EU'S ENERGY VISION
}

The main goal of this study is to show the performance of the indicators under 4 integrated main groups by using the multifactorial analysis methodology in the light of the selected indicators, by drawing attention to the integration of the energy network, which Ukraine has developed in line with the sustainable development goals, in the field of the energy economy, which has been planned with the European Union. Observing these performances is among the aims of the author's research to draw attention to the importance of reform steps Ukraine has taken in line with its sustainable development goals and these reforms will be expected a positive impact on the country's accession to the EU. 17 sustainable development goals developed by UNDP, where efficiency and innovation are imperative, focus on the improvement of countries and play a role in the formation of the indicators and groups of this study. According to the results of the study, it is observed that the indicators selected for Ukraine are linked to the data used in line with the country's common goals with the EU and 2035 energy targets, as observed in the analysis results in integrated groups. The ambition of this study, which focuses on the development of Ukraine, is aimed by the author to offer an alternative and strategic perspective to small and medium-sized entrepreneurs (SMEs) in the energy sector.

Key words: sustainable development, UNDP, multifactorial analysis, energy network, small and medium-sized entrepreneurs, strategic perspectives.

JEL classification: Q01, O57, P48, C38

Introduction. The concept of sustainability, one of the most chief themes of the 21 st century, includes many meanings for states, companies, individuals. The adoption of this concept, both structurally and mentally, plays a major role in economic visions, policies and individual decisions to be developed. If something is sustainable, it means it can maintain its current state or it can renew itself. Based on this meaning of the word, the concept of sustainability; environmental, economic, and social conditions are being used to leave a sustainable world to future generations [1]. The concept of sustainable development was shaped after the report, "Our Common Future" published by the United States in 1987 [2]. According to this report, sustainability is defined as providing our daily needs and developing without compromising the ability of nature and future generations to respond to their needs. It is essential to leave a livable world to future generations in every respect and a clean natural environment that can renew itself, social conditions based on equality and welfare, and an economic system that takes care of the society and the environment. In other words, sustainability means meeting today's economic and social needs without stealing the opportunities of future generations and harming nature. It was understood that development could not be achieved only with economic growth and many different factors should be taken into consideration. Thus, the concept of 'sustainable development' was introduced to the world in 1987. In addition to economic growth, factors such as social equality, natural environment, gender equality, qualified education, the health of individuals, responsible production and consumption have been taken into consideration to increase the level of prosperity with sustainable development. From a practical point of view, if the natural resources are consumed at a rate where they cannot be renewed, a sustainable economy cannot be mentioned, because our natural resources that will maintain the economic system will be exhausted [3]. Otherwise, if it considers social sustainability, environmental sustainability will be impossible unless the necessary political arrangements are made and lifestyles are changed.

From the perspective of the sustainable development concept described briefly above, if it is observed that the energy economy is a serious sustainable development part for the countries, the policies to be developed by a country dependent on energy imports, such as Ukraine, are of great importance for future generations [4]. With this understanding, Ukraine, which is in the process of the European Union membership bid, is expected to make a serious leap in the next 15 years, in line with the reforms pursued by the European Union's energy policies and UNDP's sustainable development goals.

Analysis of the recent research and publications. There are many scientists working on the concept of sustainable development in the literature, and the most important of these are Clark C.W. and Schellnhuber H.J. According to Clark, sustainability advocates that it should be accepted as a new concept, but underlines that it is neither basic nor practical. He advocates that this concept should be considered as a bridge and should be measured as an interdisciplinary and practical application and as information [5]. Schellnhuber et al. states in a study that he has underlined that the world is heading towards a zero-carbon waste economy and pointed out that sustainable urbanization will increase [6]. 
Although the energy and environmental policies of the European Union are binding on the energy targets of the member states, it is closely related in the countries with the potential of membership in the European Union, such as Ukraine. It covers 2020 as the first stage of these targets, and then 2030 and 2050 as later years. There is a lot of literature on this subject. The targeted rates for 2020 are as follows: $20 \%$ cut in greenhouse gas emissions when it is compared with the levels of $1990,20 \%$ increase in renewable energy usage, and $20 \%$ increase in energy efficiency. The targeted rates for 2030 are at least a $40 \%$ reduction in greenhouse gas emissions, $32 \%$ renewable energy use increase, and at least $32.5 \%$ energy efficiency increase. And the final target is to create a zerocarbon economy in 2050 [7].

There are significant historical turning points, such as the European Union, which is closely related to Ukraine and the world in the field of sustainable energy, examples include the Rio Summit, the Kyoto Protocol and the Treaty of Paris [8].

The new United Nations Development Plan (UNDP), which is the continuation of the Millennium Development Goals (MDG), came into force in 2016 under the heading "Transforming our world: the 2030 Agenda for Sustainable Development". The new development agenda is a much more comprehensive and expanded action plan that does not go beyond the general line of the Millennium Declaration. The main goal of 17 Sustainable Development Goals (SDG) is to find solutions to the world's leading problem and to develop countries structurally by 2030 . Examples of these problems are hunger, education, poverty, climate change, equality, etc. [9]

In this process, where the sustainable economy is current and vital for countries, there is a period, in which economic growth models are examined. One of the biggest reasons for this is the consumption and production imbalance. Increasing consumption without economic equality is shown by the biggest reasons for this [10].

New Energy Strategy of Ukraine till 2035 was developed in line with the UNDP and EU's energy and climate targets and is divided into 3 stages. Its main purpose is to increase energy efficiency and energy security, to create a competitive system. Ukraine's goal is to complete EUUkraine energy markets integration by 2025 and ensure sustainable energy development in parallel with the European energy policies by 2035 . With all these developments, it can be interpreted as the progress of Ukraine towards its target by using the sustainable development goals of Ukraine [11].

The purpose of the article. This study aims to analyze the data obtained as a result of the combination of 4 main innovative sustainable development groups and indicators developed by the author, based on the UNDP's sustainable development targets, as a result of the multifactorial analysis of the selected indicators between $2000-2018$ years in the energy sector of Ukraine, which is a part of the author's research [12]. Examination and comparison of the energy visions of Europe and Ukraine plus the result that will emerge will contribute to the author's research and will enable companies in the energy sector to look at sustainable development goals from an alternative perspective.

Outline of the main research materials. Sustainable development policy was clarified for the first time in the EU with the 1993 Maastricht Treaty and was included in all the EU's primary legal documents after this date [13]. The sustainable development approach of the EU has determined the protection of the environment as a basic factor to be taken into consideration in all policies and decisions regarding the economy in terms of sectoral (agriculture, industry, transportation, energy, tourism, etc.). At this point, it is essential to develop environmental protection policies by preserving the competitive understanding of the economic system. The factors that will require a competitive market economy for the sustainability of the development of Europe have been determined by considering environmental policies, and there are several policy decisions in this direction [14].

At the fact reached today in the fight against climate change, the United Nation member states and the European Union are involved in energy, technology, economy, and finance, with the transition to an economy, which is the main purpose of the Paris Agreement, which is a lowcarbon and efficient resource in the world, and with an integrated approach. has agreed to radical changes in several sector areas. The meaning of this acceptance for the EU: combating climate change in Europe means opening up significant opportunities especially in employment and economic growth. Transition to low-carbon economies is accepted as an essential tool in the EU to walk towards the goal of becoming the world leader in renewable energy. The Climate-Neutral Vision drawn by the EU by 2050 can be a guide not only for the EU countries but also for the climate policies of many countries, as it leads to the development of many research and innovation programs and new market designs. With this perspective, the EU has launched a new modernization and transformation in economic policies with the 2050 Climate-Neutral Vision to implement an economic model that will not harm the climate of the planet. The claim here is to be the first major economy in the world, which is planned to become climate-neutral by the EU until 2050, which is intended to consolidate the leading position of the $\mathrm{EU}$ in combating climate change at the global level [15].

The main goal of Ukraine and the European Union in the field of energy is to integrate its systems on both sides and make it a common use network. Energy security, energy efficiency, zero-carbon economy, innovation, and research are among the areas they want to develop with integration with cooperation. The significance of Ukraine for the European Union was specified in The Energy Union Strategy in 2015, the main purpose of this strategy is to strengthen the partnership with Ukraine, reduce its dependence on energy imports and improve their infrastructure [16]. Being a geopolitically energy transit country, Ukraine is working on serious reform movements in the energy sector for the targeted integration with the European Union. As an example, in 2018, Ukraine made the new electricity reform. The main purpose of this is structural reform to realize the integration into the European Union's electrical system. Liberalization of the electricity market is a serious step for Ukraine in the European Union process and is of great position to create an economic mechanism [17]. In light of all this information, Ukraine has focused on taking serious steps in line with UNDP's SDG targets and has set targets nationally. An example of this is to improve old infrastructures and increase energy efficiency in buildings, to improve in all areas with innovation. All targets are car- 
ried out in parallel with the European electricity system integration process and the country is focused on economic relief in the coming years.

The statistical analysis part of the author's research continues with the establishment of 4 main groups as sustainable development goals. In the previous studies for these 4 groups, it was observed that 121 indicators selected for Ukraine decreased to 31 indicators as a result of the analysis. This was accomplished with the multifactorial analysis section, which was the final stage of the elimination of indicators and the research. Meantime, sources of indicators are selected from the Ukrainian national statistics service website, the World Bank data pool and the British Petroleum's 2019 annual report. Before coming to the final stage of research, the author analyzed the indicators using the minimum and maximum normalization method in the analysis section of the indicators and using the Statistica program, eliminated the high-value indicators by reference to the Cheddock scale over their correlation coefficient matrix. With this multifactorial analysis section, which is the last stage after this elimination, the weights of the indicators on the factors have been calculated and the integrated 4 main groups have been created by using the loading of the indicators. The point that the author wants to show in this study is to gather the integrated indicators under 4 main groups and to observe the performance of the indicators.

The groups and their indicators are shown below, and the properties of the indicators will be briefly discussed. All indicators are selected in line with the goals of sustainable development and are thought to contribute to the goals of Ukraine. The first group is the economy and policy group; the indicators are shown below in Table 1.

Table 1 - Indicators of the Economic and Political Group

\begin{tabular}{|l|}
\hline Gross fixed capital formation (\% of GDP) \\
\hline Exports of goods and services (\% of GDP) \\
\hline Inflation, GDP deflator (annual \%) \\
\hline Tax revenue (\% of GDP) \\
\hline GDP growth (annual \%) \\
\hline Foreign direct investment, net outflows (\% of GDP) \\
\hline Portfolio investment, net (BoP, current US\$) \\
\hline Foreign direct investment, net inflows (\% of GDP) \\
\hline Real interest rate $(\%)$ \\
\hline Final consumption expenditure (\% of GDP) \\
\hline Dynamic Use of IMF credit (DOD, current US\$) \\
\hline Manufactures imports (\% of merchandise imports) \\
\hline
\end{tabular}

When the data of the group are examined, if the indicators that draw attention are given, inflation, GDP growth, foreign direct investments can be shown. Among the SDGs that had a share in the formation of this group, the targets focused on the economy and politics. According to the research of the author, this was the group with the most indicators. The performance of the indicators will be analyzed below. It is an important issue to strengthen the economic ties with the European Union and to show the high performance of significant data such as foreign direct investment.

In terms of energy and environment, which are the main target of this research, it is seen in Table 2, there are 4 remaining indicators according to their weight as a result of the multifactorial analysis. Two of these indicators are related to the use and consumption of renewable energy. As mentioned above, the European Union's targets for renewable energy use and the fact that SDG has targets in this direction increases the importance of these indicators.

\section{Table 2 - Indicators of the Energy} and Environmental Group

\begin{tabular}{|l|}
\hline $\begin{array}{l}\text { Renewable energy consumption (\% of total final energy } \\
\text { consumption) }\end{array}$ \\
\hline Primary Energy: Consumption (Million tonnes oil equivalent) \\
\hline Electricity generation from oil (Terawatt-hours) \\
\hline $\begin{array}{l}\text { Renewable share (modern renewables) in final energy } \\
\text { consumption percentage (SDG 7.2) }\end{array}$ \\
\hline
\end{tabular}

Innovation and entrepreneurship are issues that are of great standing in the development of countries. From this perspective, in Table 3, the indicators, which are high-tech exports, merchandise trade, and the share of innovative enterprises in the industrial enterprises, are serious meters. The high performance of this data means that it will have a direct impact on the development of the country.

\section{Table 3 - Indicators of the Innovation and Entrepreneurship Group}

\begin{tabular}{|l|}
\hline High-technology exports (\% of manufactured exports) \\
\hline Time to prepare and pay taxes (hours) \\
\hline Investment in energy with private participation (current US\$) \\
\hline Firms offering formal training (\% of firms) \\
\hline $\begin{array}{l}\text { Firms experiencing losses due to theft and vandalism } \\
\text { (\% of firms) }\end{array}$ \\
\hline Patent applications, nonresidents \\
\hline Merchandise trade (\% of GDP) \\
\hline $\begin{array}{l}\text { The share of innovative enterprises in the total number of } \\
\text { industrial enterprises }\end{array}$ \\
\hline
\end{tabular}

And the latest innovative group, intellect, and social capital is the last group selected and created from within SDGs. The peculiarity of this group is that it consists of indicators that show the social development and intellectual level of the country. Technicians and researchers in the field of Research and Development observed in Table 4 are examples. This group, which will contribute to the development of the country and has indicators that have positive economic and social impact in the European Union process, has a remarkable feature in future studies. In Table 5 below, the data consisting of the combination of the data of the indicators are observed.

\section{Table 4 - Indicators of the Intellect and Social Capital Group}

\begin{tabular}{|l|}
\hline Current health expenditure (\% of GDP) \\
\hline Total number of apartments, thsd \\
\hline Smoking prevalence, total (ages $15+$ ) \\
\hline Technicians in R\&D (per million people) \\
\hline Researchers in R\&D (per million people) \\
\hline Population, total \\
\hline Birth rate, crude (per 1,000 people) \\
\hline
\end{tabular}

If the calculation of the integrated indicators for all groups is explained, the loadings obtained from the mul- 
Table 5 - Values of Integrated Groups

\begin{tabular}{|c|c|c|c|c|}
\hline & Economic and Political & $\begin{array}{c}\text { Energy } \\
\text { and Environmental }\end{array}$ & $\begin{array}{c}\text { Innovation } \\
\text { and Entrepreneurship }\end{array}$ & $\begin{array}{c}\text { Intellect } \\
\text { and Social Capital }\end{array}$ \\
\hline 2000 & 0.383873624 & 0.561632289 & 0.569085298 & 0.358092951 \\
\hline 2001 & 0.413449544 & 0.545575357 & 0.568655652 & 0.509478938 \\
\hline 2002 & 0.401082672 & 0.48686659 & 0.64678016 & 0.512982827 \\
\hline 2003 & 0.422557435 & 0.475593618 & 0.542196683 & 0.516468562 \\
\hline 2004 & 0.421855037 & 0.475803279 & 0.548629418 & 0.521123202 \\
\hline 2005 & 0.478412033 & 0.476840036 & 0.47243866 & 0.367046055 \\
\hline 2006 & 0.393096615 & 0.52297367 & 0.413882509 & 0.850753384 \\
\hline 2007 & 0.532368144 & 0.541228106 & 0.457610984 & 0.839127493 \\
\hline 2008 & 0.552571398 & 0.616658991 & 0.376026259 & 0.835133557 \\
\hline 2009 & 0.47725309 & 0.694421951 & 0.430382685 & 0.819030104 \\
\hline 2010 & 0.464403965 & 0.574569257 & 0.463824412 & 0.659599381 \\
\hline 2011 & 0.388645037 & 0.546039027 & 0.655710668 & 0.6436989 \\
\hline 2012 & 0.4233425 & 0.53265649 & 0.697776057 & 0.634278125 \\
\hline 2013 & 0.393661965 & 0.544937437 & 0.456308059 & 0.613692817 \\
\hline 2014 & 0.419337875 & 0.49013795 & 0.553339646 & 0.564284352 \\
\hline 2015 & 0.409527672 & 0.568075835 & 0.571215758 & 0.558755092 \\
\hline 2016 & 0.353297627 & 0.458759514 & 0.543697465 & 0.553650713 \\
\hline 2017 & 0.433740607 & 0.41777843 & 0.512011799 & 0.807578511 \\
\hline 2018 & 0.413000181 & 0.288633927 & 0.48415481 & 0.524056448 \\
\hline
\end{tabular}

tifactorial analysis of all indicators and the data arranged according to the normalization method of the indicators are multiplied among themselves, and then collected separately for all years. As a result of this process, the data of the integrated indicators between 2000-2018 for 4 main groups emerged. The formulation of this process is shown below.

$$
\sum_{i=1}^{n} a_{i} x_{i}
$$

The weights of indicators on the factors shown in $a_{\mathrm{i}}$, the values of indicators shown with $x_{\mathrm{i}}$, and the values of the integrated indicators are limited to $[0 \leq$ values $\leq 1]$. The significance of these data creates an alternative perspective to observe the country's performance in the light of SDGs and to set forward targets. In the future studies of the author, the reserve values of these data, and the performances of the indicators according to their reserves for each year will be evaluated. Figure 1 below is a diagram of the integrated data of the 4 main groups observed above.

When observing the chart above, there are certain points to consider. These are how groups react on some dates. For example, there are changes in the figure during the 2008 global economic crisis. These changes have occurred due to various countries' economies and other fields. When Figure 1 is examined respectively, it is observed that the group that performs by showing fragility is the Economic and Political values. As mentioned above, the history of Ukraine, which has gone through historical bends, is a serious twist on certain dates, especially the 2004 Orange Revolution time, the 2008 crisis, the 2013 Euromaidan, the 2014 inter-country conflict, and so on [18]. In the light of the electrical system integration and SDGs with the European Union, Ukraine is making serious breakthroughs economically and going in an almost stable order even though there are slight ups and downs in terms of performance. The idea of politicians and scientists for the next 10 years is that the country will make progress upwards [19]. The performance of the group, which has been in a slight descent after 2008, is progressing with a slight upward movement with 2018 .

When the energy and environment group, which is the second and main theme, is analyzed, it is observed that the group, which has been in a regular increase in the process until 2008, has experienced a decrease afterward. It should not be forgotten that there are 2 indicators including renewable energy in this group and this concept is taking more serious investments after 2015. Assuming that the new Electricity reform has taken place in 2019 and ESU 2035 has been still in its early years, the group is expected to increase in performance for the coming years. In future studies, it is thought that the level will increase with the addition of more indicators for this group.

The status of innovation and the increase of entrepreneurship in today's world is a positive development for countries. From this perspective, Ukraine is expected to host more entrepreneurs for the coming years. When the performance of the third group was perceived, a serious increase was detected in the process until 2012. It is thought that the future of entrepreneurship and innovation is bright in these times when investments in renewable energy have accelerated. It is expected that changes in many areas such as SDGs aiming to turn old infrastructure systems into an innovative structure and factories that are not productive will make a breakthrough in Ukraine.

The performance of the 4th group, which has the last data set of the research, is remarkable. The data set, which showed a significant increase between 2005 and 2006, then decreased regularly, but it peaked again in 2017. As mentioned earlier, the importance of this area has a set of indicators that directly affect the development of the country. It is foreseen that Ukraine will go faster in the direction it aims by raising its values. The EU's external dependence on energy is known in terms of oil and natural gas. One of the solutions of the Union in the face of increasing demand is to pave the way for renewable energy with energy and climate targets. Ukraine plays a major role at this point 


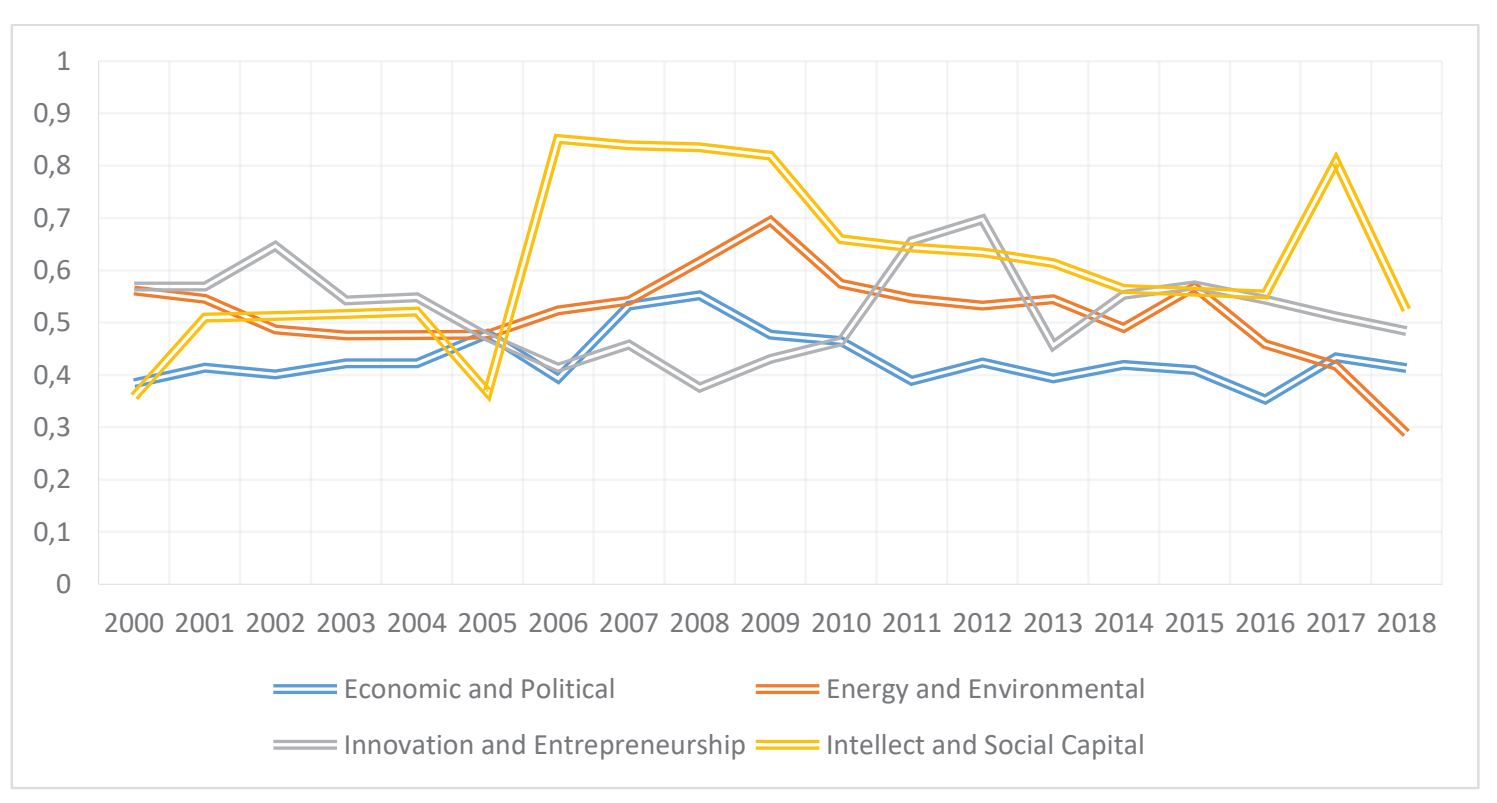

Figure 1 - Integrated Groups Performances

since Ukraine, which will adopt an innovative structure in line with the transit country position and SDG targets, is one of the countries that the European Union trusts in the field of energy and their geopolitical location. In other words, the strategic location of Ukraine on the Black Sea Region may help for the future of the EU energy investments such as are new natural gas pipeline through Ukraine or LNG transportation, etc. Besides, the implementation of multiple pipelines strategy among the EU's policy options, thus creating a diversity of resources in energy imports, is prominent issue. Since it does not have sufficient opportunities in terms of energy resources, it is aimed to add this country to the Electricity system network by helping Ukraine to correct its problematic areas [20]. When the author's data are analyzed, Ukrainian inclusive serious breakthroughs are expected for the next 10 years.

Conclusions. The contribution of the authors' study is to interpret the future goals of the European Union and Ukraine in an alternative way from the perspective of energy concept through the sustainable development goals window. The performance of Ukraine is analyzed under 4 innovative groups that the data used in the analysis section are related to SDGs. The multifactorial analysis used in the analysis section is part of the author's ongoing research and aims to give an alternative perspective to the studies in the energy sector.

Considering the analysis of the integrated data as a result of the analysis on the indicators belonging to the
4 innovative sustainable groups developed and the strategic partnership in the energy field between Ukraine and the EU, a research was conducted to see the position of the selected indicators and the indicators that Ukraine is lacking. Intellect and Social Capital group is one of the groups that draw attention as a result of the performance of the integrated indicators. It has been observed that this group has performed higher than other groups after 2005. When the Innovation and Entrepreneurship group is analyzed, the group, which has vital data such as high technology export and patent application, has experienced a recovery after 2010 and continued its performance in a bumpy course. Investments in this area are significant in the future planning of Ukraine. Another important group is Economic and Politics. The GDP-related indicators in this area group are noteworthy and it has been observed that they have a steady course in performance other than the historical break years. It is the Energy and Environmental group that concerns the investments and the common electrical system targeted with the EU. Although the indicators of this group decrease as a result of the analyzes, it has indicators that emphasize the importance of renewable energy, and its performance is in a regular course after 2013.

This study and the indicators used will contribute to the organizational and economic mechanism for Ukraine, which will be revealed as a result of the research of the author, and it is thought that it will add an alternative perspective for small and medium enterprises in the sector.

\section{References:}

1. Youmatter. 2020. Sustainability - What Is It? Definition, Principles And Examples. [online] Available at: https://youmatter.world/ en/definition/definitions-sustainability-definition-examples-principles/ (accessed 24 May 2020).

2. ARE, F., 2013. 1987: Brundtland Report. [online] Are.admin.ch. Available at: https://www.are.admin.ch/are/en/home/ sustainable-development/international-cooperation/2030agenda/un-_-milestones-in-sustainable-development/1987--brundtlandreport.html (accessed 25 May 2020).

3. Freedman, B., 2020. Chapter $12 \sim$ Resources And Sustainable Development. [online] Ecampusontario.pressbooks.pub. Available at: https://ecampusontario.pressbooks.pub/environmentalscience/chapter/chapter-12-resources-and-sustainabledevelopment/ (accessed 23 May 2020).

4. Ahuja, D. and Tatsutani, M., 2020. Sustainable Energy For Developing Countries. [online] Journals.openedition.org. Available at: https://journals.openedition.org/sapiens/823 (Accessed 18 May 2020). 
5. Clark, W.C. 2007. "Sustainability Science: A room of its own". Proceedings of the National Academy of Sciences 104: 1737-1738; published online 6 February 2007, 10.1073/pnas.0611291104

6. Rockström, J., Gaffney, O., Rogelj, J., Meinshausen, M., Nakicenovic, N. and Schellnhuber, H., 2017. A roadmap for rapid decarbonization. Science, 355(6331), pp.1269-1271.

7. Climate Action - European Commission. 2020. Climate Strategies \& Targets - Climate Action - European Commission. [online] Available at: https://ec.europa.eu/clima/policies/strategies_en (accessed 28 May 2020).

8. Center for Climate and Energy Solutions. 2020. History Of UN Climate Talks | Center For Climate And Energy Solutions. [online] Available at: https://www.c2es.org/content/history-of-un-climate-talks/ (accessed 25 May 2020).

9. UNDP. 2016. Sustainable Development Goals | UNDP. [online] Available at: https://www.undp.org/content/undp/en/home/ sustainable-development-goals.html (accessed 26 May 2020).

10. Røpke, I. (2020). Econ 101-In need of a sustainability transition. Ecological Economics, 169, 106515. doi: http://doi.org/ 10.1016/j.ecolecon.2019.106515

11. Oecd.org. 2020. [online] Available at: https://www.oecd.org/eurasia/competitiveness-programme/eastern-partners/Monitoringthe-energy-strategy-Ukraine-2035-EN-.pdf (accessed 27 May 2020).

12. Turan, U., 2020. A CORRELATION COEFFICIENTS ANALYSIS ON INNOVATIVE SUSTAINABLE DEVELOPMENT GROUPS. EUREKA: Social and Humanities, 1, pp.46-55.

13. Europa.eu. 2020. [online] Available at: <https://europa.eu/european-union/sites/europaeu/files/docs/body/treaty_on_european_ union_en.pdf $>$ [Accessed 2 May 2020].

14. Ec.europa.eu. 2020. Sustainable Development - Environment - European Commission. [online] Available at: https://ec.europa.eu/environment/sustainable-development/\#: :text=The $\% 20$ Treaty $\% 20$ of $\% 20$ European $\% 20$ Union, the $\% 20$ quality $\% 20$ of $\% 20$ the $\% 20$ environment. (accessed 15 May 2020).

15. Biresselioglu, M., Demir, M. and Turan, U., 2018. Trinity on thin ice: Integrating three perspectives on the European Union's likelihood of achieving energy and climate targets. Energy Research \& Social Science, 42, pp.247-257.

16. Europarl.europa.eu. 2020. [online] Available at: https://www.europarl.europa.eu/RegData/etudes/BRIE/2015/551310/EPRS BRI(2015)551310_EN.pdf (accessed 26 May 2020).

17. Kmu.gov.ua. 2020. Cabinet Of Ministers Of Ukraine - Energy Sector Reform. [online] Available at: https://www.kmu.gov.ua/ en/reformi/ekonomichne-zrostannya/reforma-energetichnogo-sektoru (accessed 27 May 2020).

18. BBC News. 2020. Ukraine Profile. [online] Available at: https://www.bbc.com/news/world-europe-18010123 (accessed 22 May 2020).

19. Kmu.gov.ua. 2020. Ukraine Reform Conference. [online] Available at: https://www.kmu.gov.ua/storage/app/media/reform\%20 office/Ukraine_Reform_Conference_II_web.pdf (accessed 24 May 2020).

20. EEAS - European External Action Service - European Commission. 2020. EU-Ukraine Relations - Factsheet. [online] Available at: https://eeas.europa.eu/headquarters/headquarters-Homepage/4081/eu-ukraine-relations-factsheet_en (accessed 29 May 2020).

Савченко O.I., Туран Угур

Національний технічний університет «Харківський політехнічний інститут»

\section{ДОСЛІДЖЕННЯ ЦІЛЕЙ СТАЛОГО РОЗВИТКУ УКРАЇНИ У ПОРІВНЯННІ 3 ЕНЕРГЕТИЧНИМ БАЧЕННЯМ ЄС}

Головна мета статті - проаналізувати ефективність обраних показників за чотирма основними інтегрованими групами, використовуючи методологію багатофакторного аналізу. Привернути увагу до необхідності інтеграції енергетичної мережі Украӥни, відповідно до иілей сталого розвитку у галузі енергетичної економіки. Саме ие стає необхідною складовою інтеграційних проиесів з Свропейським Союзом. Одним із завдань авторського дослідження є наголос на важливості стратегічних змін, які Украӥні необхідно здійснити відповідно до своӥх иілей сталого розвитку. Очікується, щчо саме иі реформи будуть вирішенням структурних проблем для економіки України в найближчі роки і матимуть позитивний вплив на процес вступу краӥни до Свросоюзу. Інтервал часу, за яким було проаналізовано дані, охоплює період з 2000-го до 2018-го років. В результаті всебічного аналізу даних було обрано 121 показник, i на підставі дослідження було сформовано 31 показник для використання у багатофакторній моделі. Заплановані кроки, планується спрогнозувати на наступні 10 років. Особлива увага автора була приділена 17-ти иілям сталого розвитку, які були розроблені ПРООН. Зосереджуючись на необхідності прогнозування розвитку країн, ефективність та інновації, були обрані як ключові індикатори при формуванні показників та їх угрупуванні. За результатами дослідження було визначено, шьо обрані для України показники пов'язані з даними, які використовуються відповідно до загальних иілей країни з енергетичними иілями ЄС до 2035-го року. Це спостерігається в результатах проведенного аналізу за інтегрованими групами. Дане дослідження, яке зосереджується на інноваџійному розвитку України, наџілене на визначені альтернативної перспективи для малого та середнього бізнесу в енергетичному секторі. Також, автори мають на меті привернути увагу наукової спільноти до необхідності реалізації в Украйні иілей сталого розвитку та забеспеченні підвищення ефективності економіки країни, яка має на меті підключитися до електричної системи Свропи. Це альтернативне дослідження спрямоване на розвиток країни шляхом створення стратегічних перспектив.

Ключові слова: сталий розвиток, ПРООН, багатофакторний аналіз, енергетична мережа, малий та середній бізнес, стратегічні перспективи. 